\title{
Sosyal Bilgiler Öğretmen Adaylarının Tarihsel Sorgulama Becerilerinin Değerlendirilmesi $* 1$
}

\author{
Cengiz ÖZMEN
}

Doç. Dr., Kahramanmaraş Sütçü İmam Üniversitesi, Eğitim Fakültesi cengizozmen001@hotmail.com Orcid ID: https://orcid.org/0000-0001-5014-1299

\section{Samet KUŞCU}

Kahramanmaraş Sütçü İmam Üniversitesi, Sosyal Bilimler Enstitüsü, Yüksek Lisans Öğrencisi, sametkuscu46@gmail.com

Orcid ID: https://orcid.org/0000-0002-0811-493X

\section{Öz}

Sosyal Bilgiler öğretmen adaylarının tarihsel sorgulamaya dayalı araştırma becerilerinin değerlendirilmesine yönelik bu çalışma nitel desende tasarlanmış olup veri toplama aracı olarak literatürde kabul görmüş tarihsel sorgulamaya dayalı araştırma becerisini oluşturan alt beceriler doğrultusunda hazırlanan sorular ve ilgili tarihsel kanıtların yer aldığı çalışma yaprakları kullanılmıştır. Araştırma sonucunda öğretmen adaylarının tarihi kanıtlar üzerinde benzer sorular sordukları, özgün yanıtların sinırlı olup derinlemesine ele almakta zorluk yaşadıkları, tarihi kanıtları ele alırken aidiyet duygusuyla hareket edip nesnel bir bakış açısı oluşturmakta zorlandıkları, sorgulamayarak var olanı betimledikleri görülmüştür. Tarihi konularda verileri yorumlamaktan ziyade ön bilgilerinden istifade ettikleri ve duygusal cevaplar verdikleri görülmektedir. Ancak bazı öğretmen adaylarının diğer becerilere nispeten önyargı veya çarpıtmaları tespit edebildikleri, görüşlerini tarihsel kanıtlarla destekleme konusunda ise yeterli beceriyi gösteremedikleri anlaşılmaktadır.

Anahtar Kelimeler: Tarihsel Sorgulama Becerileri, Sosyal Bilgiler, Öğretmen Adayları Tarihsel Düşünme Becerisi.

\footnotetext{
${ }^{1}$ Makale Geliş/Kabul Tarihi: 07.02.2019 / 10.06.2019

* Bu çalışma 7. Uluslararası Sosyal Bilgiler Eğitimi Sempozyumu'nda sunulan bildirinin genişletilmiş halidir.

Künye Bilgisi: Özmen, C., Kuşcu, S. (2019). Sosyal Bilgiler Öğretmen Adaylarının Tarihsel Sorgulama Becerilerinin Değerlendirilmesi. Kahramanmaraş Sütçü İmam Üniversitesi Sosyal Bilimler Dergisi, 16 (2), 342-362. DOI: 10.33437/ksusbd.523967
} 


\title{
Evaluation of Historical Questioning Skills of Social Studies Teacher Candidates
}

\begin{abstract}
The aim of this research, which is designed as a qualitative research, is to examine the use of social studies teacher candidates' historical inquiry-based research skills. In this study, as the data collection tool, the worksheets containing the questions prepared in the direction of the sub-skills forming the historical inquiry-based research skill accepted in the literature and the related historical evidence are used. As a result of the research, it was seen that the teacher candidates had asked similar questions on the historical evidence, they had difficulty in dealing with the limited and in-depth answers of the historical evidence, they were sensitive to the historical evidence and acted with the sense of belonging and were forced to form an objective point of view. In historical matters, it is seen that they have used their preliminary knowladge and feeling instead of interpretation of numerical data. Some of the candidates questioned, but they were forced to use historical evidence.
\end{abstract}

Keywords: Historical Inquiry Skills, Social Studies, Ability Of Historical Thinking Of Teacher Candidates.

\section{GİRIŞ}

İnsanoğlunu diğer canlılardan ayıran en önemli özelliklerden olan düşünme yetisi, etrafımızda gerçekleşen hadiseleri anlamlandırmamıza yardımcı olmaktadır. Düşünmenin Türk Dil Kurumu'ndaki tanımını incelediğimizde, zihnin bir konuyla ilgili bilgileri karşılaştır, aralarındaki bağlantıları inceleyerek bir yargıya ya da karara varma etkinliği (TDK, 2018), olarak ifade edildiğini görmekteyiz.

Bilginin hızla çoğaldığ1 günümüz ortamı, düşünme becerisi edinmek ve devamlılığını sağlama gerekliliğini ortaya çıkarmaktadır (Demirkaya, 2008). Düşünme çok boyutlu olmalıdır çünkü tek boyutlu bir düşünme kişiyi veya toplumu durağanlığa, farklılıklara anlayışla yaklaşmayan bir konuma iter (Narin ve Aybek, 2010).

Düşünme zor bir süreçmiş gibi algılanabilir. $\mathrm{Bu}$ da düşünmenin karışık olmasından ileri gelmektedir. Bir konu veya durum hakkında düşünürken; sahip olduğumuz bilgileri, beklentilerimizi, duygularımızı, mantığımızı, 
yaratıcılığımızı bir anda kullanmamız gerekmektedir (Bono, 1999). Belki de düşünmeyi ayrıcalıklı ve cazip duruma getiren de bu özelliğidir.

Düşünme, taktik ve kıyaslama gücü olarak da ifade edilebilir. İnsanı diğer varlıklardan farklı kılansa bu güçtür. İnsan diğer varlıkların hâkimiyeti altına girmez tam tersine onları kendi hâkimiyeti altına alır, düşünme de bunda önemli bir paya sahiptir (Guitton, 2011).

Düşünmenin önemini fark etmeyen veya fark etmek istemeyenler, genelin taşıdığ 1 yerleşmiş inanç ya da görüşlere şüpheyle yaklaşanları hoş görmezler çünkü düşünmenin getireceği kazançların değerinin farkında değillerdir (Buny, 2010). İnsan amacina ulaşmak için kendine güvenmeli, sahip olduğu kabiliyetlerini dikkate almalı, kendi gücünün farkında olmalıdır. Bu özellikleri hayata geçirmesinde de yine düşünme yatmaktadır (Peale, 2003). İnsan beyni algıladığı bilgileri mukayeseler yaparak ayrıştırır, bir araya getirir böylece bilgileri kavrar ve sonuçlara ulaşır. Karar vermek gayesiyle birçok fikri bir araya getirerek bu fikirlerden yeni neticeler elde etmek için girişilen zihinsel faaliyet olan düşünme, bir nevi hayattaki tüm faaliyetlerin ve ifadelerin harmanlanıp şekil almasidır (Benazus, 2011).

Düşünmek zihni kullanarak bilgi üretiminde çaba sarf etmektir. Bilinenleri tekrar etmek olarak algılanmamalıdır (Başar, 2013). Soru sormak düşünmeyi harekete geçiren önemli bir yöntemdir. Çünkü düşünmenin ortaya çıkmas1 konuyla alakalı çeşitli soruların sorulmasıyla başlar. Nitelikli bir eğitimcinin öğrencisini düşünmeye yönlendirmek için çeşitli sorular sorması gereklidir. Fakat sorular yüzeysellikten ziyade düşünmeyi harekete geçirecek özellikte olmalıdır (Saygin, 2011).

Düşünme faaliyetinin genel olarak birçok boyutu olduğu ifade edilebilir ama uygulama sahası hayat ya da daha üst düzeyde disiplinler olmasından dolayı uygulamada farklılaşabilmektedir. Tarih disiplini de kendine özgü felsefesi, bilgi yapısı ve metodolojisiyle farklı düşünmeyi gerekli k1lmaktadır. Alanyazında bu durum tarihsel düşünme ya da tarihsel düşünme becerileri olarak adlandırılmaktadır.

Tarihi olayları ele alırken bilimsel bir bakış açısı takınmalı, zihnimizi bir takım beceriler çerçevesinde harekete geçirmeliyiz. Tarihi konularda düşünme sürecine başlarken devreye "Tarihsel Düşünme Becerisi” girmektedir. Bu becerinin etkin bir şekilde kullanılması için gerekli bilgilerin edinilmesi ve uygulanmas1 gereklidir.

Tarihsel düşünme; tarihi anlamlandırmak, önceki dönemler hakkında fikirler ileri sürmek aynı zamanda bizden önceki tarihsel zaman dilimiyle günümüz arasında bağ oluşturabilmek için öğrencilerin kazanmasında önemli olan bir 
kabiliyettir. Böylece geçmişte var olan bir olayı o dönemde yaşayanların bakış açısıyla görmüş oluruz (Dilek, 2002).

Tarihsel düşünme, bize geçmişin zihinde yeniden canlandırılmasını sağlar. $\mathrm{Bu}$ canlandırmayı yapmak başkasının zihnine hapsolmak anlamına gelmez. Bu bize verimli ve eleştirel bir bakış açısı sağlar (Collingwood ve Dinçer, 1996).

Tarihsel düşünme becerileri öğrencilerin tarihsel akış süreci içerisinde akıl yürütmelerine, geçmişte yaşanan olay ve olgular arasında ilişki kurmalarını sağladığı gibi geçmiş ve bugün arasındaki bağlantıyı kurmalarına da yardımcı olur (MEB, 2018).

Tarihi materyallerin belirlenmesinde tarihçinin yönelimleri ve bakış açısı etkilidir. Yine tarihi olaylardan çıkaracağımız anlamların bizim birikimlerimize göre şekillenmesi söz konusudur çünkü geçmiş bizim bildiklerimizden ibaret değildir. Yine de tarihi eser bizim bildiklerimizden veya varsayımlarımızdan tamamen ayrilamaz (Jenkins, 1997).

Alan yazın incelendiğinde tarihsel düşünme becerilerinin kendi içerisinde alt basamaklara ayrıldığı görülmektedir. Bunların: Kronolojik Düşünme, Tarihsel Anlama, Tarihsel Analiz ve Yorumlama, Tarihsel Sorgulamaya Dayalı Araştırma Becerileri, Tarihsel Konular-Analiz ve Karar Verme Becerileri (URL-1), adı altında sıralandıkları görülmekte olup araştırmada ise " Tarihsel sorgulamaya dayalı araştırma becerisi " üzerine odaklanılmıştır.

Tarihsel Sorgulamaya Dayalı Araştırma Becerisi; Geçmiş dönemleri öğrenmenin birçok yolu olmakla birlikte en dikkat çekeni kişinin araştırmasıyla ve araştırma sonucunda elde ettiklerini yazıya dökmesiyle mümkündür. Bunu yaparken de geçmişle ilgili bizi araştırmaya iten ve çözmeyi düşündüğümüz sorun açıkça belirlenmeli, olası çözüm yolları geliştirilmeli, çözüm yolları uygulamaya konmalı ve böylece problem durumu yanitlanmalıdır. Birey bu süreci uygularken tarihsel sorgulamaya dayalı araştırma becerisinin gerektirdiği özellikleri de edinmektedir. Birey bilim insanının takındığı sorgulayıcı bir tutumla çalışmalarını inceleyerek geçmiş hakkında bilgi sahibi olmaktadır (Demircioğlu, 2009).

Yaşadığımız dönemde teknolojinin etkisiyle bireyler çok sayıda bilgiyle karşılaşmaktadır. Bu durumda kişilerin gerçekle yanlışı, bilginin güvenilirliğini, ön yargıları, çarpıtmaları fark edecek becerileri edinme zorunluluğu doğmaktadır (Doğan, 2007).

Sorgulamak hayatın her alanında kullanılan bir beceridir. İnsan etrafında tanık olduğu olayları anlamlandırmak için daima sorular sorar. Hayatımızda önemli olan bu beceri eğitim yoluyla edinilip geliştirilebilir (Güneş, 2016). 
Tarih derslerinin veriliş sürecinde özellikle ders kitaplarına aşırı bağl1lıktan dolayı tarihi kanıtlardan, metinlerden ya da kalıntılardan uzak bir eğitim yapılmakta ve böylece tarihi kanıtlar yapay hale gelerek yorumlarla gerçekler birbiriyle karışmaktadır (Şimşek, 2008).

Öğrenmeyi amaçlayanlar; eğitimin gerçekleştirildiği ortamlarda, sorgulamaya dayalı yaklaşımla sorgulama becerilerini bir araya getirerek kendi çabalarıyla çalışmalarını yürütüp bilimsel doğrulara ulaşarak, ülkesi ve diğer toplumlar için sorumluluklarının bilincinde olma yolunda iyi bir başlangıç yapmaktadır (Karademir, 2013).

Bir problem durumu üzerinde sorgulama yapılması, öğrencinin öğrenme sürecine dâhil edilmesini sağlar. Birey edindiği yeni bilgilerle dış dünyadaki durumlar arasında bağlantılar kurarak, hayatta kalmaya ve karşılaşması muhtemel sorunların üstesinden gelmek için neler yapması gerektiği bilincine ulaşır (Bektaş ve Horzum, 2010).

Sosyal Bilgiler dersinin okullarımızda verilmesinin birçok amacı bulunmaktadır. Öğrencilerin içerisinde yaşadıkları topluma uyum sağlayan, hak ve sorumluluklarının farkında olan, kullanan aynı zamanda savunan bireyler yetiştirmenin yanı sıra tarih bilincinin oluştuğu, edindiği bilgileri sorgulama süzgecinden geçiren etkin bireyler yetiştirilmesi de amaçlanmaktadır (MEB, SBDÖP, 2018).

Sosyal Bilgiler içeriği itibariyle tarihsel konuları da bünyesinde taşımaktadır. Tarihi konuların sorgulayıcı bir şekilde ele alınmasında öğretmenlere büyük görevler düşmektedir. Bu doğrultuda ilerleyen dönemlerde öğretmenlik görevini üstlenecek olan ögretmen adaylarının tarihsel sorgulamaya dayalı araştırma becerilerine sahip olması gerekmektedir. Alan yazın incelendiğinde tarihsel düşünmeye yönelik birçok çalışmanın yapıldığı görülmekle birlikte tarihsel düşünmenin bir bölümü olan tarihsel sorgulamaya dayalı araştırma becerisi üzerine müstakil çalışmaların yeterli olduğu söylenemez. Bu doğrultuda tarihsel sorgulamaya dayalı araştırma becerisinin derinlemesine bir şekilde ele alınması bakımından çalışma farklılık göstermekte olup alana bu konuda katkı sağlayacağı düşünülmektedir.

Çalışmada Sosyal Bilgiler öğretmen adaylarının, Tarihsel Sorgulamaya Dayalı Araştırma Becerilerinin birtakım tarihi kanıtlar vasıtasıyla incelenerek tarihsel sorgulamanın gerektirdiği belirli kazanımlara sahip olma durumları tespit edilmeye çalış1lmıştır.

\section{YÖNTEM}


Sosyal Bilgiler öğretmen adaylarının, tarihsel araştırma yaparken tarihi kanıtları sorgulayıp sorgulamadıklarını incelemeye yönelik yapılan bu çalışmada nitel araştırma deseni benimsenmiştir. Nitel araştırmalar, gözlem, görüşme ve doküman analizi gibi nitel veri toplama yöntemlerinin kullanıldığı, algıların ve olayların doğal ortamda gerçekçi ve bütüncül bir biçimde ortaya konmasına yönelik bir sürecin izlendiği araştırmalardır (Yıldırım ve Şimşek, 2003).

\section{Çalışma Grubu}

Çalışma, 2017-2018 eğitim öğretim yılında Sosyal Bilgiler Öğretmenliği Bölümü’nde öğrenim gören 11 kız 6 erkek toplam 17 Sosyal Bilgiler birinci sınıf öğretmen adayının katılımı ile gerçekleştirilmiştir.

\section{Veri Toplama Aracı}

Veri toplama aracı araştırmacılar tarafindan oluşturulmuş olup, alan yazında kabul görmüş tarihsel sorgulamaya dayalı araştırma becerisini oluşturan alt beceriler doğrultusunda hazırlanan soru ve ilgili tarihsel kanıtların yer aldığ çalışma yaprakları kullanılmıştır. Veri toplama aracı oluşturulurken becerileri karşılayabilecek tarihsel kanıtların seçimine dikkat edilmiş olup çeşitli dönemlerde sosyal bilgiler ders kitabı olarak okutulan materyallerdeki tarihi kanıtlardan faydalanılmıştır. Kanıtlar iki tarihçi ve iki tarih eğitimcisi olmak üzere toplamda dört uzman tarafından incelenmiştir. Böylece gerekli düzenlemeler yapıldıktan sonra tekrar uzmanlara danışılarak son hali elde edilmiştir. Katılımcılardan tarihsel kanıtları inceleyip, kendilerine yöneltilen sorular doğrultusunda yanıtlamaları istenmiştir, böylece öğretmen adaylarının tarihsel verileri sorgulayıcı bir bakış açısıyla inceleyip incelemedikleri derinlemesine bir şekilde elde edilmeye çalışılmıştır.

\section{Verilerin Analizi}

Araştırmada elde edilen veriler içerik analizine tabi tutulmuştur. İçerik analizinde verileri açıklayabilecek kavram ve ilişkilere ulaşmak temel amaçtır. Betimsel bir yaklaşımla fark edilemeyen bazı kavramlar ve temalar daha derin bir işleme tabi tutulduğundan içerik analiziyle keşfedilebilir (Yıldırım ve Şimşek, 2003).

Araştırma, öğretmen adaylarına yöneltilen tarihsel sorgulamaya dayalı araştırma becerisinin alt kazanımlarıyla sınırlıdır.

\section{BULGULAR}

Araştırmanın bu kısmında Sosyal bilgiler öğretmen adaylarının, tarihsel sorgulamaya dayalı araştırma becerilerini değerlendirmek amacıyla yöneltilen 
sorular doğrultusunda ulaşılan veriler aşağıda tablolar halinde ilgili tarihi kanıtla birlikte sunulmuştur.

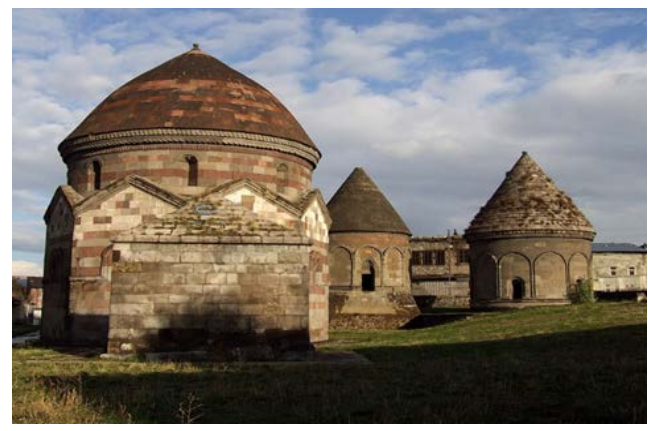

Kanit 1

Tablo 1. Kanıtla ilgili tarihsel sorular sormaya yönelik bulgular

\begin{tabular}{lll}
\hline $\begin{array}{c}\text { Kanıt 1 hakkında merak } \\
\text { ettikleriniz nelerdir? }\end{array}$ & f & \% \\
\hline Ne zaman yapıldı? & 11 & 65 \\
Kim tarafından yapıldı? & 10 & 59 \\
Hangi mimari tarzdan yararlanıldı? & 9 & 53 \\
Ne amaçla yapıldı? & 8 & 47 \\
Nerede yer almakta & 6 & 35 \\
$\begin{array}{l}\text { Yapımında kullanılan malzemeler } \\
\text { neler? }\end{array}$ & 3 & 18 \\
Kitabede yazılanlar nelerdir? & 2 & 12 \\
Hangi medeniyete ait? & 1 & 6 \\
Nasıl bir matematiksel işlem & 1 & 6 \\
kullanıldı? & &
\end{tabular}

Tablo 1. incelendiğinde kanıtta yer alan tarihi eser hakkında merak ettikleriniz nelerdir sorusuna katılımcıların en çok yönelttikleri sorular \%65 ile ne zaman yapıldığı, en az ise $\% 6$ oranıyla hangi medeniyete ait olduğu ve nasıl bir 
matematiksel işlemle yapıldığı yönünde sorular yöneltmişlerdir. Tablo 1, genel olarak incelendiğinde öğretmen adaylarının ekseriyetle bilgi ve kavramaya yönelik sorular sordukları, üst düzey düşünme becerisi gerektiren analiz, sentez ve değerlendirme tarzı sorular sormadıkları, sordukları soruları tek cümle veya birkaç kelimeyle ifade etmeye çalıştıkları görülmüştür. Örneğin;

ÖA. 16. $\dot{I}_{c ̧}$ kısımları, yazıtları, kim zamanında yapıldı $\breve{g}$, hangi mimari tarzın kullanıldi $\breve{g} \imath$ ?

ÖA. 11. Hangi dönemde kim tarafindan yapıldı̆̆g?

ÖA. 1. Nerede olduğu kimin yaptırdi ̆̆ merak ederim.

ÖA. 15. Yazıtları, iç kısımları.

Şeklinde sorular yöneltmişler, cümleyi tamamlayamamışlar ya da düzgün cümle kuramamışlardır. Ayrıca öğretmen adaylarının sordukları sorular tahlil edildiğinde benzer cümleler kullandıkları dikkat çekmektedir. Fakat bir iki adayın diğerlerine nispeten daha nitelikli sorular sordukları görülmüştür. Örneğin;

ÖA. 14. Mimari açıdan nasıl yapıldı̆̆ı bunun yanında bu mimari eseri yapanların matematiksel olarak nasil bir yol izlediğini merak ettim?

ÖA. 12. İnşa edilen bu eserlerin daha çok hangi amaçlar doğrultusunda kullanıldiğl, eserlerin inşası sırasında ne tür materyallerin kullanıldi $\breve{g l}$, üzerine işlenen figürlerin kabartmaların hangi devlete ya da medeniyete ait olduğu, neden kubbe biçiminde ya da neden koni biçimli tavan yapısı kullanıldığını merak ediyorum.

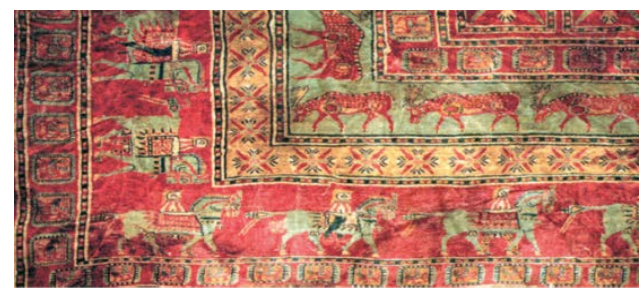

Kanit 2 
Tablo 2. Kanıttan yola çıkılarak elde edilen tarihsel verilere yönelik bulgular.

\begin{tabular}{|c|c|c|}
\hline $\begin{array}{c}\text { Kanıt 2'yi } \begin{array}{c}\text { incelediğinizde } \\
\text { toplumla ilgili neler söyleyebiliriz? }\end{array}\end{array}$ & $\mathbf{f}$ & $\%$ \\
\hline Hayvancılıkla uğraşmışlar & 11 & 64 \\
\hline Savaşçı bir toplum & 9 & 53 \\
\hline At hayatlarında önemli & 8 & 47 \\
\hline Dokumacilıkla ilgilenmişler & 4 & 24 \\
\hline Avcılıkla uğraşmışlar & 3 & 18 \\
\hline Geyik figürleri & 1 & 6 \\
\hline Renkler canlılıklarını koruyor & 1 & 6 \\
\hline Renkli iplikler üretmişlerdir & 1 & 6 \\
\hline Düşüncelerini halıya dokumuşlardır & 1 & 6 \\
\hline
\end{tabular}

Tablo 2. incelendiğinde ilgili tarihi eserden katılımcılardan elde edilen verilere bakıldığında; en fazla \%64 oranıyla hayvancılıkla uğraştıkları $\% 53$ savaşçı bir toplum olduğu, \%47 ile göçebelik ve atın önemine vurgu yaptıkları görülmektedir. En az ise \%6 oranıla geyik figürleri, renklerin canlılıklarını koruduğu, renkli ipliklerden üretildiği ve düşüncelerini halıya dokudukları bilgilerine ulaştıkları görülmektedir.

Öğretmen adaylarının verdikleri cevaplardan anlaşıldığ 1 üzere görselden yola çıarak bazı yorumlamalar yaptıkları ve bazı tarihsel veriler elde ettikleri söylenebilir. Ancak çok fazla düşünme becerisi gerektiren veriler olmadığı, herkesin kolaylıkla ulaşabileceği tarzda olduğu söylenebilir. Aşağıda bazı adayların verdiği cevaplar olduğu gibi yansıtılmıştır.

ÖA.14. Bu halı figüründe dikkatimi en çok çeken şey halıda bulunan at ve savaşçılar olmuştur. Yani bu halıya bakarak bunu yapan toplumun savaşçı bir toplum olduğunu görebiliriz.

ÖA.4. Halı üzerinde bulunan at figürü savaşçılık özelliklerinin geliştiğini gösterir. Geyik motifi ve diğer hayvan motifleri hayvanları evcilleştirdiklerini gösteriyor. 
Bir öğretmen adayı ise görseli daha derinlemesine sorgulamış ve aşağıdaki ifadeleri kullanmıştır

ÖA.12. Üzerinde bulunan at ve üzerinde süvari bulunan figürler Türklerin savaş̧̧ bir toplum olduğunu, ayrıca tarihte de bildiğimiz üzere Türklerin atları ilk evcilleştiren toplum olduğunu bilmekteyiz. Aynı şekilde burada da kanit olarak bu özelliği görebilmekteyiz. Kızıl renkte boyanmış geyik figürlerine bakacak olursak Türklerin avcı bir toplum olduğunu söyleyebiliriz. Ayrıca halıda kullanılan malzeme itibariyle (keçe, yün) hayvancılıkla uğraşmışlar ve kullanılan renklere baktığımızda canlılıklarını hala koruyor olması şaşırtıcı. Bu da onları çeşitli bitkileri kaynatarak renkli iplikler ürettiğinin kanıtıdır. Halıda bulunan diğer farklı geometrik şekil ve motifler ile aslında bize o halıyı dokuyan kişi hakkinda ya da düşünceleri hakkinda bilgi vermekte çünkü Türk hatunları düşüncelerini ve sevgilerini bu şekilde halılara dokumuşlardır.

Burada öğretmen adayının, renkli iplikler ürettiklerinden bahsetmesi muhtemelen ön bilgisinden hareketle çıkarım yaptığı ve kanıtın görünmeyen yönünü vurguladığı bundan dolayı diğerlerine nazaran daha üst düzey bir düşünme gerektiren kanıt elde etmeye çalıştığı söylenebilir.

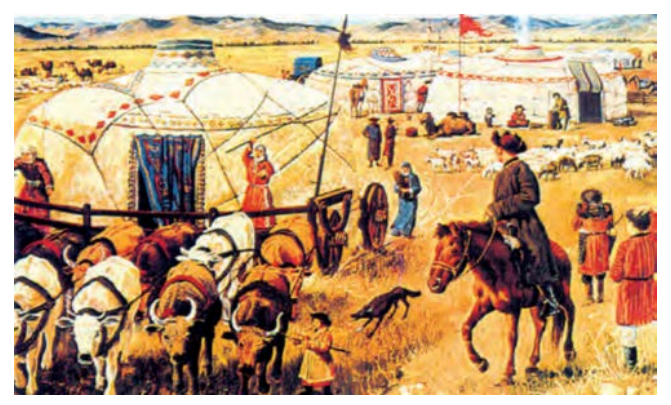

Kanit 3

Tablo 3. Tarihsel verileri sorgulamaya yönelik bulgular

\begin{tabular}{lcc}
\hline $\begin{array}{l}\text { Kanıt 3'ü incelediğinizde Türkler } \\
\text { hakkında neler söylersiniz. Sizce } \\
\text { Türkleri yeterince yansitabilmiş } \\
\text { midir? }\end{array}$ & f & \% \\
\hline Göçebelik & & \\
Hayvancılık & 11 & 65 \\
Tarım & 10 & 59 \\
\hline
\end{tabular}




$\begin{array}{lll}\text { At } & 4 & 24 \\ \text { Çadır } & 3 & 18 \\ \text { Kültürel devamlılık } & 1 & 6 \\ \text { Oba } & 1 & 6 \\ \text { Yardımseverlik ve dayanışma } & 1 & 6 \\ \text { Halıcılık } & 1 & 6 \\ \text { Köy hayatı } & 1 & 6 \\ \text { Avcılık } & 1 & 6\end{array}$

Tablo 3 incelendiğinde öğretmen adaylarının soruya verdikleri cevaplara evet yansıtmıştır diyerek tablodaki ifadeleri kullanmışlardır. Öğretmen adayları, $\% 65$ 'lik bir oranla göçebelik kavramından, \%59 oranında hayvancılıktan, en az ise $\% 6$ 'lık bir oranla kültürel devaml1lık, halıcılık, köy hayatı gibi ifadeler kullanmışlardır.

Aşağıdaki ifadelerden de anlaşılacağ 1 üzere öğretmen adaylarının sorgulama yapmak yerine görseli olduğu gibi yorumlama çabası içine girdikleri görülmektedir. Örneğin;

ÖA. 1 Görselde yer alan çadırlar, atlar, çite koşulmuş hayvanlarla Türklerin özelliklerini yansıtabilmiştir.

ÖA. 14. Yansıtabilmiştir. Göçebe bir toplum oldukları için hayvancılıkla uğraşmışlardır.

ÖA. 5. Tarım ve hayvancılık ile uğraşmışlardır. Göçebe yaşam hâkim olabilir.

ÖA.4. Avcılı̆̆a önem veren bir yapıdadırlar.

Osmanlı Kuruluş dönemiyle araştırmalar yapan H. A. Gibbons'a göre:

' Osmanlılar Anadolu'nun en uzak köşesine yerleştikleri için doğudan göçlerle gelen Türklerle temasa geçme firsatlart olmamıştır. Osmanlılar, Anadolu'ya geldikten sonra Müslümanlı̆̆ kabul etmişlerdir. Bizans sinırları yönünde genişleyen bu küçük grup, din değiştirme ve evlilikler yoluyla büyük kısmı Rumlardan oluşan yerli halk ile karışmış-tır. Bunun sonucunda da tarih 
sahnesine Osmanlı adıyla yeni bir ırk çıkmıştır. Bu yolla Osman Bey'in 400 çadırlık aşiretinin yaklaşık on kat arttı̆̆ını belirten Gibbons, Osmanlıların büyük bir güç olmasında doğudan gelen unsurların değil Rumlardan Osmanlılara sı̆̆ınanların ve din değiştirenlerin önemli rol oynadı̆̆ını söyler. " Dolayısıyla Gibbons, Osmanlıları meydana getiren gücün Asya kökenli değil, tamamen Avrupa kökenli unsurlar olduğunu iddia eder. (MEB, 2017: 35)’”

\section{Kanit 4}

Tablo 4. Olguların göz ardı edilmesi veya icat edilmesi yoluyla önyarg1, çarpıtma ve propaganda amacı taşıyıp taşımadığını incelemeye yönelik bulgular.

\begin{tabular}{lll}
\hline $\begin{array}{l}\text { Kanıt 4'ü incelediğinizde Gibbons'un } \\
\text { ifadelerini nasıl karşılıyorsunuz, neden? }\end{array}$ & f & \% \\
\hline Katılmıyorum & 16 & 94 \\
Kanıt Yok & 4 & 24 \\
Osmanlı Asya kökenlidir & 4 & 24 \\
Objektif değil & 3 & 18 \\
Osmanlı Birçok milletten oluşur. & 3 & 18 \\
Osmanlı Kayı boyundandır & 3 & 18 \\
Hoşgörünün göstergesi & 2 & 12 \\
Asılsız bir iddia & 2 & 12 \\
Tarihi Kaynaklarda Osmanlı Türk’tür & 2 & 12 \\
Çamur at izi kalsın & 1 & 6 \\
Doğru olabilir etkilenmiştir & 1 & 6 \\
Osmanlı asimile olmuştur & 1 & 6 \\
$\begin{array}{l}\text { Osmanlı Anadolu'ya gelmeden } \\
\text { Müslümandı }\end{array}$ & 1 & 6 \\
Osmanlı bir ırk değil devlettir & 1 & 6 \\
\hline
\end{tabular}


Tablo 4. incelendiğinde; katılımcıların biri hariç diğerleri Gibbons'un ifadelerine katılmadığını belirterek eleştirmişlerdir. 4 katılımcı söylenenlerin kanıtlarının olmadığını, 1 katılımcı ise Osmanlı'nın Asya kökenli olduğunu belirtmişlerdir. İfadelerden anlaşıldığı üzere 4 öğretmen adayı ön bilgilerinden hareket ederek metni eleştirmişlerdir. Adaylardan biri ise Gibbons'un ifadelerine katılmadığını ancak doğru olabileceğini ifade etmiştir. Ancak Gibbons'un görüşlerine eleştirel bir yaklaşım göstermiş, ön yarg1 ve çarpıtma olduğunu belirtmiş olsalar da kendi görüşlerini kanttlarla desteklememişlerdir. Örneğin;

ÖA. 15. Bu ifadelere katılmıyorum Osmanoğulları Oğuzların Kayı boyundan gelmiştir Bu ifade ne Türklerin kayltlarında ne de Rumların arşivlerinde bulunmamaktadır Bu ifadeler asılsızdır.

ÖA. 1. Ben bunu Çamur at izi kalsın şeklinde karşıllyorum Yedi kıtaya hükmetmiş bir Cihan devletinin övüp yüceltenler olduğu gibi Yerip aşağılamaya çalışanlarda olacaktır.

ÖA. 13. Osmanlılar Anadolu'ya gelmeden önce de Müslümandl. Osmanlılar Anadolu'daki Türk boyları da egemenliği altına almıştır sadece Rumların Osmanlı'ya sı̆̆ınması ile Osmanlılar büyümemiş.

Bir öğretmen adayı ise metni sorgulamaya gerek duymadan direk metinden etkilendiğini ve doğruluğunu kabul ettiğini aşağıdaki ifadeleriyle belirtmiştir.

ÖA. 14. "Yani bu burada sonradan Müslüman olan ve devşirilmiş olan insanlarla kurulup genişlediğini anlıyorum Yani Osmanlı'yı oluşturan sadece Türkler değil diğer Tebaa vardır" sözleriyle ifade etmiştir.

ÖA. 12. ise metne şüpheyle yaklaşmış karşılaştırma yaparak "Kısmen doğruluk gösterebilir Osmanlı beyliği evet Anadolu Rumlarlyla bir arada yaşamış, onlarla etkileşim içine de girmiş olabilir, ancak aynı zamanda Osmanlı Devleti Anadolu beylikleri ile de etkileşim içerisindedir ve ayruca çeyiz, ticaret evlilik yoluyla doğudaki Türklerle de etkileşim halinde bulunmuşlardır. Bu bağlamda Osmanlı'yı oluşturan gücün Asya kökenli değil tamamen Avrupa kökenli olduğu iddiası Bana göre doğru değil. Çünkü hem etkileyen hem de etkilenen iki unsurdan bahsediyoruz. İkisi de birbirinden etkilenmistir, biri birinden fazla diyemeyiz.".

Şeklinde kendi görüşünü belirtmiştir. İki aday ise fazla yorum yapmaya gerek görmemişler ve görüşlerini aşağıdaki gibi belirtmişlerdir.

ÖA. 4. Hayır katılmıyorum

ÖA. 17. Asya kökenlidir Avrupa değil 
'Türk çocuğu ecdadını tanıdıkça daha büyük işler yapmak için kendinde kuvvet bulacaktır. "(Kocatürk,1999:115)

\section{Kanit 5.}

Tablo 5. Yorumların tarihsel kanıtlarla desteklenmesine yönelik ulaşılan bulgular

\begin{tabular}{lll}
\hline $\begin{array}{c}\text { Atatürk sizce neye dayanarak böyle } \\
\text { bir ifade kullanmış olabilir? }\end{array}$ & f & \% \\
\hline Geçmişteki Başarıları & 6 & 35 \\
Türk tarihinin büyüklü̆̈̈u & 2 & 12 \\
Ataların azmi & 1 & 6 \\
Savaş stratejileri & 1 & 6 \\
Destanlarla dolu bir tarih & 1 & 6 \\
Çok ileride seviyede medeniyet & 1 & 6 \\
Türklerin Dünyaya katkıları & 1 & 6 \\
Önemli gelişmeler & 1 & 6 \\
Teşkilatlanma & 1 & 6 \\
Şanlı zaferler & 1 & 6 \\
\hline
\end{tabular}

Tablo 5 incelendiğinde Atatürk sizce neye dayanarak böyle bir ifade kullanmış olabilir sorusuna katılımcıların \%35'i geçmişteki başarılar , \%12'si Türk tarihinin büyüklüğü, diğerleri ise \%6'l1k bir oranla Şanlı zaferler, Ataların azmi, savaş stratejileri, destanlarla dolu bir tarih çok ileri bir medeniyet, Türklerin dünyaya katkıları, Önemli gelişmeler, teşkilatlanma gibi yüzeysel cevaplar verdikleri görülmektedir. Örneğin;

ÖA. 14. Tarihte atalarımızın başarıları ve dünyaya katklları önemli olgularına dayanarak ileride Türk insanlarının daha büyük işler başaracağını ifade etmiştir.

ÖA. 12. . Atatürk Türk milletinin tarihte yapmış olduğu önemli gelişmelere devlet yönetimine askeri teşkilatı savaş stratejileri oluşturduğunu kastetmiştir 
ÖA.16. Türk ecdadını çok ileride seviyede medeniyet olduğunu belirtmiştir.

\section{Tartışma, Sonuç ve Öneriler}

Araştırmada Sosyal Bilgiler öğretmen adaylarının kendilerine yöneltilen sorulara ve tarihi kanıtlara yönelik verdikleri cevaplar incelendiğinde, aşağıdaki değerlendirmelerde bulunulabilir.

Tarihsel dokümanlar, tanıkların anlatıları, mektuplar, günlükler, buluntular, fotoğraflar, tarihi mekânlar, sanat eseri ve mimari eserlerden hareketle tarihsel sorular sorar; becerisi doğrultusunda katılımcıların yönelttiği sorular incelendiğinde tarihi kanıta yönelik özgün sorular yerine yalnızca akla ilk gelen yüzeysel soruları yöneltmişlerdir. Literatürde çokça kullanılan, eğitim-öğretimde de sık sık başvurulan soru türlerinin bile bireysel katılımcı olarak incelendiğinde kullanmadıkları görülmektedir. Soruların ortalamaları alındığında katılımcı başına 3 sorunun yöneltildiği anlaşılmaktadır. Neticede elde edilen veriler incelendiğinde öğretmen adaylarının genel itibariyle bilgi ve kavrama düzeyinde sorular sordukları, anali, sentez, değerlendirme, karşılaştırma, iliş̧kilendirme tarzında üst düzey zihinsel beceri gerektiren soruları yöneltmedikleri ve çeşitli düzeylerde soru sorma becerisini gösteremedikleri anlaşılmaktadır. Turan (2016)'nın çalışmasında da tarih öğretmenlerinin öğrencilere tarihsel sorular sorabilme becerisinin tamamen kazandırıldığını düşünenlerin oranı \% 13,2 olduğunun belirlenmesi ve Şimşek(2008) 'in çalışmasında incelenen tarih ders kitaplarında yer verilen toplam 1265 sorunun \% 88 inin bilgi ve kavrama düzeyinde olduğu tespiti araştırmamızın sonuçlarıyla örtüşmektedir. $\mathrm{Bu}$ doğrultuda Tarihsel Sorgulamaya dayalı araştırma becerisinin gelişimi için soru sormanın öneminin kavranması yönünde çalışmalara ağırlık verilerek öğrencilerin çok farklı düzeylerde soru sorma kabiliyetinin gelişmesine yardımcı olunabilir.

Kütüphane ve müze koleksiyonlar, tarihi mekânlar, tarihi fotoğraflar, gazeteler, günlükler, dergiler, belgesel filmler, tanı anlatıları, nüfus sayım sonuçları, vergi kayıtları, istatistiksel derlemeler ve ekonomik göstergeler gibi çok değişik kaynaklardan tarihsel veri elde eder, becerisi doğrultusunda öğretmen adaylarının cevapları ele alındığında, adayların tarihi kanıtı inceleyerek bir takım bilgiler elde ettikleri ve kendilerince bir sonuca ulaştıkları görülmektedir. Ancak katılımcıların önceden aldığı eğitim süreci ve mevcut bölümleri dikkate alındığında, sorgulama becerisini çok fazla sergileyemedikleri, yüzeysel diyebileceğimiz veriler elde ettikleri söylenebilir. Katılımcıların bir kısmının yanıtları incelendiğinde bir iki kelimeyle ifade ettikleri, özenli bir şekilde cevap verenlerin ise az olduğu görülmektedir. Öğretmen adayları her ne kadar bazı çıkarımlarda bulunmuşlarsa da Tablo 2'de de görüldüğü gibi fazla bir sorgulama yapmadıkları sadece gördüklerini tasvir ettikleri anlaşılmaktadır. 
Örneğin, geyiklerden yola çıkarak Türklerin hayvancılıkla uğraştıkları sonucuna ulaşmışlar ama neden koyun ya da sığır değil de geyik olduğuna dair bir sorgulama yapmamışlardır. Ya da geyikle iklim ve coğrafi bölge bağlantısı kuramamışlardır. Bir öğretmen adayının ise görseli daha derinlemesine sorguladığ 1 görülmektedir. Burada muhtemelen aday ön bilgilerini harekete geçirmiştir. Bu doğrultuda tarihsel sorgulama becerisinin hatta tarihsel düşünme becerilerinin her birinin tarihsel kavramayla yakından ilişkili olduğu düşünülebilir. Öztürk, Bilgen, ve Bilgen, (2017)'in çalışmasında öğretmen adaylarının mezun olduğu lise türünün sorgulama becerisinde etkili olduğu bulgusu dikkate alındığında çalışmaya katılan öğretmen adaylarından 8 kişinin Anadolu, 5 kişinin meslek ve 4 kişinin normal liseden mezun olduğu dikkate alındığında lise türlerinin farklı olması ve henüz birinci sınıfta olmalarının etkili olduğu söylenebilir. Turan (2016)'ın, çalışmasında tarih öğretmenlerinin öğrencilere tarihsel veri elde edebilme becerisinin tamamen kazandırıldığını yönünde düşünceye sahip olanların oranın \% 12,6 olduğu dikkate alındığında çalışmamızın sonuçları hakkında bizi aydınlatmaktadır. Bu doğrultuda ders kitapları oluşturulurken içerisindeki soruların düzey dağılımları bilimsel çerçevede oluşturularak sorgulayıcı bakış açısının gelişimi desteklenerek sorgulamaya dayalı araştırma becerisinin gelişimine katkı sağlanabilir.

Tarihsel verilerin ait olduğu toplumsal, siyasal ve ekonomik bağlamı açıklayarak bu verileri sorgulama, geçerliğini, güvenirliğini, yeterliğini, gerçekliğini, iç tutarllğını ve bütünlüğünü değerlendirir, becerisi doğrultusunda öğretmen adaylarının değerlendirmeleri incelendiğinde, kendilerine sunulan tarihi kanıtı sorgulamak yerine olduğu gibi betimleyen ifadeler kullandıkları görülmektedir. Örneğin kanıtta Türklerin bir dönemi konu edilmesine rağmen öğretmen adayları bunu sorgulamadan sadece görsele odaklanmış ve olduğu gibi tasvir etmişlerdir. Hâlbuki öğretmen adaylarından beklenen görselde Türklerin hayat tarzının belki belli bir döneminin doğru olarak yansitabildiğini, bunun yanında ileriki dönemlerde yerleşik hayata geçtiklerini büyük medeniyetler kurduklarını düşünerek bunun eksik kaldığını, Türkleri tam olarak yansıtabilmesi için bütün dönemleri içeren görsellere ya da kanttlara yer verilmesi gerektiğini belirtmemişlerdir. Ayrıca Türklerin hayat tarzının bir dönemini yansıtmış olsa bile görselde yer almayan bazı maddi ve manevi unsurlara değinilmediği ve bunun eksik olduğunu ifade eden olmamıştır. Örneğin demircilik, gök tanrı inanc1, ticaret, alet yapımı, halı kilim dokuma, teşkilatçılık vb. unsurlar eksik olmasına rağmen öğretmen adayları bunu sorgulamamışlardır. Hatta kadınların sosyal hayattaki rolleri görselde kısmen yer almasına rağmen buna da hiç değinilmemiştir. Bazı öğretmen adayları görselde yansıtılan yarı göçebe hayat tarzını tarımla veya köy hayatıyla ilişkilendirmişlerdir. Bu durum göçebelik kavramının ne anlama geldiğini tam olarak bilmediklerini, köy yaşamının ve tarımla uğraşmanın göçebeliğin bir unsuru olduğunu zannettikleri algısı oluşturmaktadır. Bayramoğlu (2016)'nun çalışmasının gözlem sonuçlarında da 
öğretmenlerin değerlendirme düzeyinde çalışmalara yer vermediklerinin görülmesi çalışmamızın sonuçlarını destekler niteliktedir.

Olguların göz ardı edilmesi veya icat edilmesi yoluyla önyargl, çarpıtma ve propaganda amacı taşılyı taşımadiğını inceler, becerisi doğrultusuna sunulan kanıt için, öğretmen adayları, ön yargı ve çarpıtma olduğunu ifade etmişler ve ön bilgilerini harekete geçirerek eleştirel bir yaklaşım sergilemişlerdir. Ancak alternatif bir kaynak sunmamışlardır. Öğretmen adaylarının aidiyet duygusu kapsamında metni eleştirdikleri düşünülmektedir. Bayramoğlu(2016) ‘nun çalışmasında da öğrencilerde tarihsel düşünme becerisi dâhilinde önyargıların farkında oldukları gözlenmiş, fakat gözlem neticesinde bu becerinin kullanılmadığı tespit edilmiştir. Turan (2016)'nın, çalışmasında ise öğretmenlerin, öğrencilerin ön yarg1, çarpıtma ve propaganda amacı taşıyı taşımadığını inceleyebilme becerisinin tamamen edindiğini düşünenlerin oranı \% 9,4 olduğu belirlenmiştir. Bu doğrultuda tarihsel sorgulamaya dayalı araştırma becerisinin bu kısmında yeterli düzeyin neden elde edilemediği de diğer araştırmaların sonuçları da dikkate alındığında fikir edinmemize yardımcı olmaktadır. $\mathrm{Bu}$ doğrultuda Tarihsel sorgulamaya dayalı araştırma becerisi geliştirilirken aynı zamanda eleştirel düşünme becerisi de dikkate alınmalı ve bu becerinin kazanılmasında zenginleştirilmiş yöntemlere başvurulmalıdır. $\mathrm{Bu}$ amaçla, yapılan araştırmalar incelenerek eğitim-öğretim sürecine daha etkili bir şekilde yansit1labilir.

Yüzeysel görüsler yerine sağlam bir muhakemeye dayalı iddialar ortaya koyarken yorumlarını tarihsel kanıtlarla destekler, becerisi doğrultusunda yöneltilen soruya, öğretmen adaylarının verdikleri cevaplar incelendiğinde; şanlı zaferler, ataların azmi, savaş stratejileri, destanlarla dolu bir tarih, çok ileri bir medeniyet, önemli gelişmeler, teşkilatlanma gibi genel ifadeler kullanmışlardır. Öğretmen adayları, ifadelerini somut veya birinci elden kaynak diye ifade edebileceğimiz kanıtlarla desteklemedikleri, yalnızca yorumlarda bulundukları ya da ilgili sözden ne anladıklarını ifade ettikleri görülmektedir. Bu durumun tarihsel kavrama ve bilgi eksikliğinden kaynaklanabileceği de düşünülebilir. Tarih bilgisinin yetersizliği, görüşlerini sağlam bir kanıta dayandıramamada etkili olduğu düşünülmektedir. Tarihsel bilgi yetersizliğinden dolayı öğretmen adaylarının sorgulama becerisini de kullanamadıkları düşünülmektedir. $\mathrm{Bu}$ doğrultuda Işık (2011)'ın çalışmasında birinci el kaynak kullanımının öğrencilerin başarısını arttırdığı düşünüldüğünde ve Bayramoğlu (2016)'nun çalışmasında, Sosyal Bilgiler öğretmenlerinin çoğunluğunun birinci el kaynak kullanmadıklarını tespit edilmesi ve öğrencilerde tarihsel düşünme becerisi alt başlıkları kapsamında "konuyu farklı kaynaklardan araştırma isteği", "tartışma etkinlikleri”, "birincil ve ikincil kaynakları ayırt etme davranışları gözlemlenmemiş olması çalışmanın mevcut sonucu hakkında bir fikir oluşturmaktadır. Buna göre birinci el kaynak kullanımının, görüşleri sağlam bir 
kanıta dayandırma hususunda önemli olduğu söylenebilir. Turan (2016)'nın çalışmasında da tarih öğretmenlerinin tarihsel kanıtlarla destekleyebilme becerisinin tamamen kazandırıldığı yönünde kanaat belirtenlerin oranının \% 10,2 olduğu tespit edilmiştir. İlgili çalışmalar da mevcut çalışmanın sonucuyla paralel bir özellik gösterdiğgi düşünüldüğünde öğretmen adaylarının düşüncelerini ifade ederken kanıt kullanmada yeterli donanıma sahip olmadıkları sonucu ortaya çıkmaktadır. Işık (2008)'ın çalışmasında derslerde doküman kullanımının öğrencilerde tarih bilgisi ve tarihsel düşünme becerilerini geliştirdiği görülmüştür. $\mathrm{Bu}$ doğrultuda dersler içerisinde birinci elden farklı kaynak kullanımına ağılık verilerek sorgulamaya dayalı araştırma becerisinin gelişimine katk1 sağlanabilir. Tarihsel sorgulamaya dayalı araştırma becerisinin gelişimi için bizzat uygulama tarzında çalışmalara yer verilmesi tavsiye edilebilir.

Çalışma neticesinde elde edilen veriler değerlendirildiğinde çalışmanın muhatabı öğretmen adaylarının tarihsel sorgulamaya dayalı araştırma becerilerinin yeterli düzeyde olmadığı söylenebilir. Eğitim süreci içerisinde bu becerilerin kazanılamadığı düşünüldügünde doğal olarak öğretmen adayları da tarihsel sorgulamaya dayalı araştırma becerisini uygulama aşamasında sıkıntı yaşamaktadır. Demircioğlu (2009)'nun çalışmasında tarih öğretmenlerin büyük bir kısmının $(\% 83,6)$, aldıkları eğitim süresince ve sonrasında tarihsel düşünme becerilerinin neler olduğuna dair eğitim almadıklarını belirtmiş olmaları öğretmen adaylarının lise eğitimi süresince gerekli beceriyi edinememiş öğretmenlerden eğitim almış olma ihtimalinden dolayı bu beceriyi göstermekte güçlük yaşamalarını veya pratiğe dönüştürmekte zorlanmalarının bir nedeni olarak düşünülebilir. Özmen (2015)' in Sosyal Bilgiler öğretmen adayları üzerinde yaptığı çalışmasında da öğretmen adayları tarihsel düşünme becerilerinin farkında olmaları ve önemini bilmelerine rağmen yeterince eğitim almadıkları ve uygulama konusunda eksik oldukları anlaşılması çalışmamızın sonuçlarıyla örtüşmektedir.

\section{KAYNAKÇA}

Başar, Hüseyin, (2013). Nasıl Düşünelim? (1. Baskı b.). Ankara: Pegem Akademi.

Bayramoğlu, Alev Çelik, (2016). Sosyal Bilgiler Programında Yer Alan Tarih Konularının Tarihsel Düşünme Becerileri Açısından Değerlendirilmesi. Yüksek Lisans Tezi, T.C Adnan Menderes Üniversitesi, Aydın

Bektaş, Mustafa ve Horzum, M. Barış, (2010). Otantik Öğrenme. Ankara: Pegem Akademi. 
Benazus, Hanri, (2011). Düşünce: İnsana Tanınan Ayrıcalık. İstanbul, Türkiye: Hiperlink/Bizim Kitaplar. 04 16, 2018 tarihinde http://eds.b.ebscohost.com/eds/detail/detail?vid=4\&sid=ccacd813-6ee948faa557af5e0266113d\%40sessionmgr101\&bdata=Jmxhbmc9dHImc210ZT1l ZHMtbGl2ZQ\%3d\%3d\#AN=571015\&db=nlebk adresinden erişilmiştir.

Bono, Edward. (1999). Altı Şapkalı Düşünme Tekniği (2. Baskı b.). (E. Tuzcular, Çev.) İstanbul: Remzi Kitapevi.

Buny, John Bagnell. (2010). Düşünme ve Konuşma Özgürlüğü (1. Bask1 b.). (M. Özdil, Çev.) İstanbul: Çalış Ofset.

Collingwood, Robin George ve Dinçer, Kurtuluş, (1996). Tarih Tasarımı. Ankara: Hiperlink (Firm). doi:610344

Demircioğlu, İsmail Hakkı, (2009, Ocak). “Tarih Öğretmenlerinin Tarihsel Düşünme Becerilerine Yönelik Görüşleri”, Milli Eğitim Dergisi, 39(184), ss. 228-239.

Demirkaya, Hilmi, (2008). Sosyal Bilgilerde Düşünme ve Soru Sorma Becerileri. B. Tay, Ve A. Öcal İçinde, Özel Öğretim Yöntemleriyle Sosyal Bilgiler Öğretimi (s. 392). Ankara: PEGEM Akademi.

Dilek, Dursun. (2002). Tarih Derslerinde Öğrenme ve Düşünce Gelişimi (2. baskı b.). Ankara: Pegem A Yayınları.

Doğan, Yasin, (2007). Sosyal Bilgiler Öğretiminde Tarihsel Yazılı Kanıtların Kullanımı. Doktora tezi, Gazi Üniversitesi, Eğitim Bilimleri Enstitüsü, Ankara:

Guitton, Jean, (2011). Düşünme Sanatı (1. Baskı b.). (C. Perin, Çev.) Ankara: Elips Kitap.

Güneş, Firdevs, (2016). “Eğitimde Sorgulamanın Gücü”, Bartın Üniversitesi Eğitim Fakültesi Dergisi, 5(2), ss. 188-204.

Işık, Hasan, (2008, EKİM). "Tarih Öğretiminde Döküman Kullanımının Öğrencilerin Başarılarına Etkisi’”, Kastamonu Eğitim Dergisi, 16, ss. 389-402.

Işık, Hasan, (2011). “Ortaöğretim Tarih Derslerinde Birinci ve İkinci El Kaynaklar ile Etkinlik Temelli Ders İşlemenin Öğrencilerin Tarihsel Düşünme Becerilerine Etkisi”. Turkish Studies, 6(1), ss. 1323-1337. 
Jenkins, Keith, (1997). Tarihi Yeniden Düşünmek (1. b.). (B. S. Şener, Çev.) Ankara: Dost Kitabevi.

Karademir, Çiğdem, (2013). Öğretmen Adaylarının Sorgulama ve Eleștirel Düşünme Becerilerinin Öğretmen Öz Yeterlik Düzeyine Etkisi. Doktora tezi, Adnan Menderes Üniversitesi Sosyal Bilimler Enstitüsü, Aydin.

Kocatürk, Utkan, (1999), Atatürk'ün Fikir ve Düşünceleri, Atatürk Araştırma Merkezi. Ankara: Semih Ofset

MEB. (2018). Ortaöğretim Tarih Dersi Öğretim Programı (9, 10 ve 11. sinıflar). 43. Ankara.

MEB. (2018). Sosyal Bilgiler Dersi Öğretim Programı. Sosyal Bilgiler Dersi Öğretim Programı (İlkokul ve Ortaokul 4, 5, 6 ve 7. Sınıflar). Ankara.

MEB. (2017). 9. Sınıf Tarih Ders Kitabı, MEB Yayınları

Narin, Nuray ve Aybek, Birsel, (2010). “ílköğretim İkinci Kademe Sosyal Bilgiler Öğretmenlerinin Eleștirel Düşünme Becerilerinin İncelenmesi”, Ç.Ü. Sosyal Bilimler Enstitüsü Dergisi, 19(1), ss. 336-350.

Özmen, Cengiz, (2015, July). "Social Studies Teacher Candidates Views On Historical Thinking Skills. Educational Research And Reviews", 10(14), 2031-2042. doi:10.5897 / ERR2015.2294 adresinden erişildi.

Öztürk, Yasemin; Bilgen, Zehra ve Bilgen, Sezgin, (2017, Temmuz-Aralık). 'Sorgulama Becerileri İle Kendi Kendine Öğrenme Becerileri Arasındaki İlişki: Temel Eğitim Öğretmen Adaylarına Yönelik Bir Araştırma" Sinop Üniversitesi Sosyal Bilimler Dergisi, 1(2), 179-214. 2018 tarihinde http://dergipark.gov.tr/download/article-file/381939 adresinden erişildi

Peale, Norman Vincent. (2003). Olumlu Düşünmenin Gücü (14. Basım b.). (Ş. Cüceloğlu, Çev.) İstanbul: Sistem Yayıncılık.

Saygın, Oğuz, (2011). Düşünce Becerisi (5. Baskı b.). İstanbul: Karma Kitaplar.

Şimşek, Ahmet, (2008). 'Tarih Öğretiminde Sorgulamacı Yaklaşım Çerçevesinde Soru Sorma Becerisi ve Lise Tarih Ders Kitaplarının Durumu’', Uluslararası İnsan Bilimleri Dergisi, 5(1), ss. 1-15. 08 31, 2018 tarihinde:https://www.jhumansciences.com/ojs/index.php/IJHS/article/view/436/281 adresinden erişildi 
Turan, Refik, (2016). 'Tarih Öğretmenlerinin Öğrencilere Temel ve Tarihsel Düşünme Becerilerinin Kazandırılma Düzeyine İlişskin Görüşleri’”, Journal of Turkish Studies, 11(Volume 11 Issue 14), 705-705. https://doi.org/10.7827/TURKISHSTUDIES.

TDK. (2018, 04 10). Türk Dil Kurumu. http://www.tdk.gov.tr: http://www.tdk.gov.tr/index.php?option=com_bts\&arama=kelime\&guid= TDK.GTS.5acc9a935e3034.09752860 adresinden erişildi.

URL-1:University of California, L. A. (2018). https://phi.history.ucla.edu/nchs/historical-thinking-standards/. 08 30, 2018 tarihinde https://phi.history.ucla.edu/: adresinden erişildi

Yıldırım, Ali ve Şimşek, Hasan (2003). Sosyal Bilimlerde Nitel Araştırma Yöntemleri (3. b.). Ankara: Seçkin Yayınları.

\section{Ek Kaynakça}

Kanıt 1. Evirgen, Ömer Faruk. (2016) 7. Sinıf Sosyal Bilgiler Ders Kitabı. Y1lmaz, Ahmet. (Ed.) Ankara: Ekoyay yayıncılık

Kanıt 2. Altun, Adnan, Elmac1, Süleyman. ve Beldağ, Adem. (Edit.). (2017). MEB 5. Sınıf Sosyal Bilgiler Ders Kitabı

Kanıt 3. Karakaya, Fatih. - Midilli, Aliye. ve Güven, Necati. (2017) 6. Sınıf Sosyal Bilgiler Ders Kitabı. Sema, C. Ş. (Edit.). Ankara: Sevgi yayınları 